\title{
PLANNING STUDY FOR THE REALITY OF SCHOOL GARDENS DESIGN IN DUHOK CITY (HIGH SCHOOLS AS A CASE STUDY)
}

\author{
Yousif Ali Abdulrahman ${ }^{*}$ and PrWeen Mohamed ShareeF ${ }^{* *}$ \\ *Dept. of Horticulture, College of Agriculture, University of Duhok,Kurdistan Region -Iraq \\ ** Dept. of Planning, College of Engineering and, University of Duhok, Kurdistan Region -Iraq
}

Received: December 6, 2018; Accepted for Publication: March 6, 2019)

\begin{abstract}
This study was performed in the Duhok city which is the center of Duhok governorate in 2012. The study aimed to the analysis of the reality of gardens and open spaces schools and the distribution of the different spaces (classroom, construction, concrete squares, paths and allocated green spaces) of 10 selected high schools in duhok city and comparing with the local and international standard to meet the desires of our students in future in the gardens and green spaces field around their schools by use architectural plan Analysis, observations and personal interviews. The study come to several results and conclusions can summarized as the following the lack of achievement of schools gardens in high schools of duhok to fundamental objective, not owning the schools the ideal garden model. Only $27.66 \%$ of the space represented for gardens of total area of the site of ten elected samples and the effectively utilized space of this area about $52.88 \%$, while the remaining space $\mathbf{4 7 . 1 2 \%}$ was unexploited without any activity and vitality, where $90 \%$ of these schools open space failed to achieve global or international standard and $60 \%$ of them subjected to local standard. Also these gardens were lacked to the gardening arts, as well as there were randomized in number, types and distribution of plants in that gardens.
\end{abstract}

KEY WORDS: landscape design, school gardens, green spaces, high schools in duhok city.

\section{INTRODUCTION}

$\mathbf{T}$ The school garden term is understood as a green land around a school or area located in the near to the school, typically surrounded by a fence, which was planted with a variety of plants, equipped with various tools used for farming (Rasol, 1988; Chawla, 1994; Fleszar and Gwardys-Szczęsna, 2009). The school gardens have characteristics distinguish from other types of gardens and have other functions: the school garden has become one of the most important elements at scientists and researchers in the field of education, psychology, scientific, sports, health, environment and social and physical activities, to increase students' artistic taste and aesthetic sense and to help students absorb scientific lessons related to agriculture, life sciences, the environment and the economic (Pranis and Hale, 1999; Waliczek and Zajicek, 1999).'

As experiments proved that the use of school garden a standard curriculum was an effective way to increase and enhance the student information (Harvey, 1989). Recreation and psychology treatment where the psychology changes are made when human has enjoyment from the beauty of the nature (Relf, 1992). Also had health and environmental functions which increase in carbon dioxide concentration leads to decreased student's performance on concentration test and increased their complaint of health problems as compared to classes with lower carbon dioxide levels. This occur because during photosynthesis process, in school gardens plants make use of carbon dioxide in the air to manufacture food while $\mathrm{O}_{2}$ is given out as the by-product, this makes the air we breathe cleaner and more $\mathrm{O}_{2}$ is taken to the brain (Inko-Tariah, 2010)

In the modern era the importance of gardens and external spaces of schools have been increased because of the theories and methods that embody the interaction of the student with the natural environment, which was the only place that student find comfort and conducting activities, it is as a grade in school for being one of the stimulating factors affecting the process of learning and teaching of the various sciences (Lohr and Relf, 2000). Blair (2009) showed that educators widely use school gardens for experiential education; researchers have not 
systematically examined the evaluative literature on school-gardening outcomes. Skinner and Chi (2012) found a model of essential motivation in garden-based education. The model was used to create reliable and valid measures of key constructs, and to guide the practical discovery of motivational processes in garden-based learning. The school was characterized by possessing private gardens which used to be a place for teaching since the Pharaohs time (Lownds, 2000). Inko - Tariah (2010) conclusion that the benefits of the school garden, no excuse is enough not to have one in any school as those that don't have enough space can put them in pots. Integrate the garden to the classroom and give students the joy of experiencing nature first hand. Having potted plants in the classroom has been found to enhance positive attitude and increase academic achievement of the students.

The goals of this study is to survey and put the design indicators and the theoretical base to be followed for designing gardens and external open spaces of high school for students to satisfy a side of their desires for their study level. To reach the basic goal requires achieving a number of secondary goals as the following:

1- Definition of the school gardens concept, its functions, there different usages the main parts that make the garden, planning and design standards which are related to gardens, and external open spaces of schools.

2 - To be taken account the design and planning basics when designing or establishing the school gardens.

3 - Evaluating the reality of the selected high schools in the Duhok city.

\section{Methodology}

The study area and case study

This study was carried out in Duhok city which is the center of Duhok governorate. It is located in the north-western part of Iraq, at $585 \mathrm{~m}$ above sealevel and $470 \mathrm{~km}$ north of Baghdad at the latitude $\left(36^{\circ} 51^{\prime} 43.56^{\prime \prime} \mathrm{N}\right)$ and longitude $\left(42^{\circ} 59^{\prime} 51.47^{\prime \prime} \mathrm{E}\right)$ in the city center. The territory area is about (107) $\mathrm{km}^{2}$.

As well as the lack of studies related to the planning of school gardens, its design, and in particular high school in the Kurdistan Region, and here is the basic problem of the research, which includes the lack of a clear vision, holistic, and objective of the local standards and design indicators which should be available in school gardens for students of high school.
In order to achieve the overall objectives of the research, it relies on two essential aspects to make the content of this work, which are including the analysis of the reality of the case for gardens and spaces of open spaces in high schools of the Duhok city, depending on the main indicators identified in the theoretical study, using several methods to gather informations, and survey them through personal observations as well as analysis and measurement schemes for different models for schools, in order to extract the output and conclusions which emerged from the study with recommendations which we find it appropriate and to be taken into account and adopted in the design and establishment of school gardens in the future.

\section{General description of selected samples}

1- Kawa high school for boys ${ }^{1}$ : The school is located in a Gri-Basi neighborhood next to Shoresh Street and Sefin restaurant located on the street (statue of the poet Ahmad Khani) where the numbers of students are (950), The building was established in 1948, the built with one floor, and interface building is to the north.

2- Amad high school for girls ${ }^{2}$ : The school is located in Si-Girga, a leading point is (the Union of Kurdistan Scientists). The building was established in 1994, the numbers of students are about (320), and the front of the school is located in the West, where there are well open spaces.

3- Midia high school for girls ${ }^{3}$ : The school is located in Zozan neighborhood; a known point is (Emergency Hospital). The building was established in 1998, the number of students are (1107) student, and the direction of the school towards the south, where there are very good open spaces.

4- Zirka high mixed school ${ }^{4}$ : The building was established in (2007), which is located in Zirka area, the number of students are (569) males and females, and the direction of the school towards the south, next to Zirka oil station. There are good external spaces.

5- Sefin high school for girls ${ }^{5}$ : The school is located in Reza neighborhood. The building was established in 1998, the number of students is (870) student and the direction of the school is towards the east, the nearest known point (Qazi Mohammad Mosque).

6- Zanisty high school for boys ${ }^{6}$ : The school is located in Sarhildan neighborhood. The building was established in (1995), the number of students is (1721), and the direction of the school is 
towards the south, the nearest famous point is (AlAsri market), where there are outdoors spaces.

7- Nsebin high school for boys ${ }^{7}$ : The building was established in (2006). It's located in (Nisebin) area, the numbers of students are (209), and the direction of the school is towards the south, there are well open spaces, the nearest known point is (Awaz Stadium).

8- Lavan high school for girls $^{8}$ : The school is located in Zari- Land neighborhood. The building was established in (2008), the numbers of students are (771). The school direction is towards the south, where there are well external spaces close to (Zari Land apartments).
9- Awaz high school for girls': The school is located in Gri- Basi neighborhood. The building was established in (2003). The number of students is (948), and the direction of the school is towards the north. Where there are well open spaces, the nearest famous point (Mamozin square).

10- Simarkh high school for boys ${ }^{10}$ : The school is located in Shakhki area. The building was established in (2008), the number of students is (517), and the direction of the school is towards the east. There are open spaces; the nearest famous point is (Judy mosque).

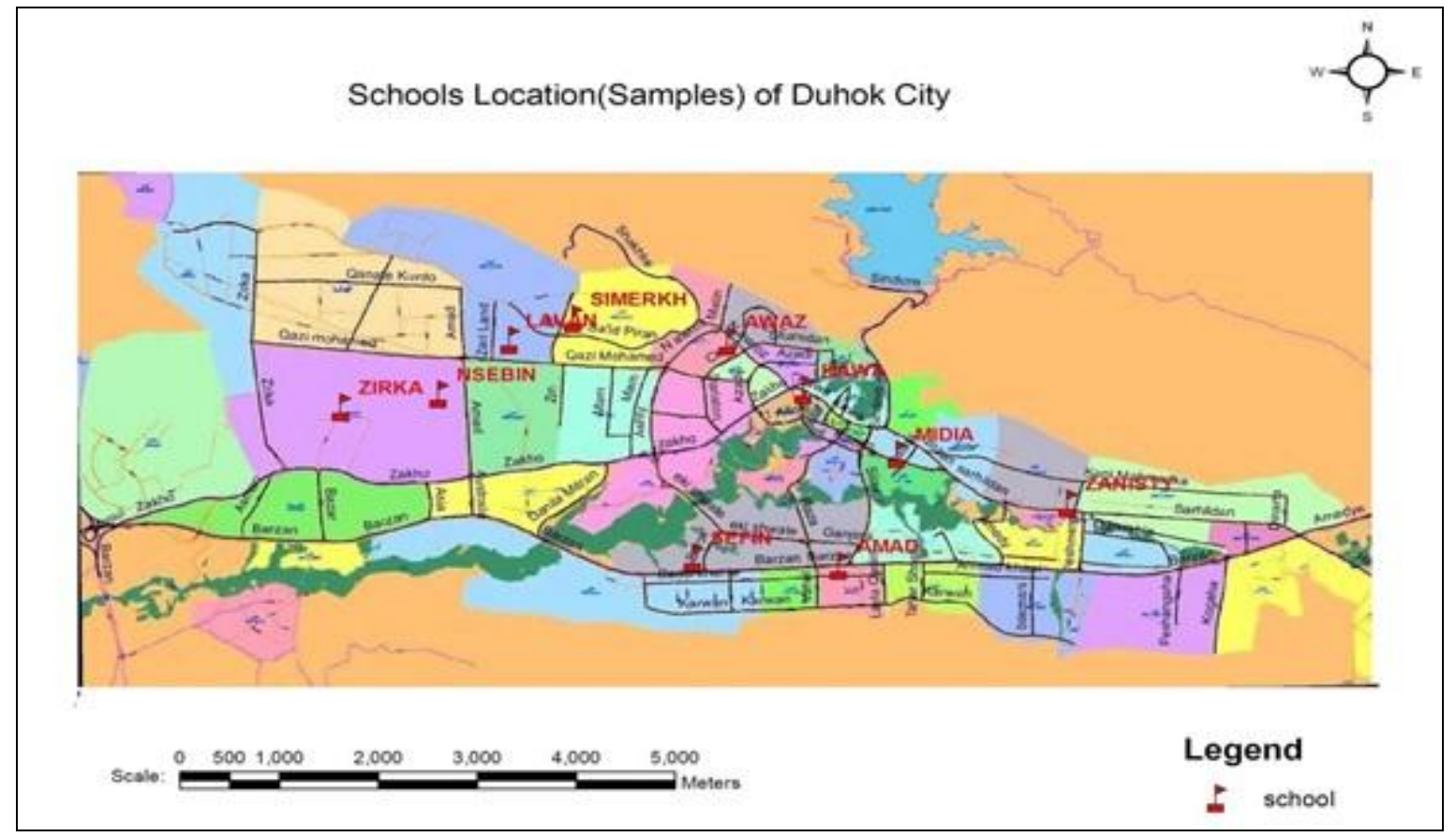

Figure (1): Schools locations chosen as samples in Duhok city

\footnotetext{
${ }^{1}$ A personal interview with the Director of School Mr. Kovan Hasan Hasan, 3/2/2012.

${ }^{2}$ A personal interview with the Director of School Ms. Shireen Abbas Muhammad, 6/2/2012.

${ }^{3}$ A personal interview with the Director of School Ms. Jian Muhammed Ridha, 7/2/2012.

${ }^{4}$ A personal interview with the Director of School Mr. Husain Ibrahim Muhammad, 3/2/2012.

${ }^{5}$ A personal interview with the Director of School Mr. Zhiaa Muhammad Maasom, 4/2/2012.

${ }^{6}$ A personal interview with the Director of School Mr. Omar Ahmed Qasim, 4/2/2012.

${ }^{7}$ A personal interview with the Director of School Mr. Zeia Uhanna Gorgis, 7/2/2012.

${ }^{8}$ A personal interview with the Director of School Ms. Agharid Mahmood Abdullah, 6/2/2012.

${ }^{9}$ A personal interview with the Director of School Mr.Rizgar Sadiq Abdulrahman, 7/2/2012.

${ }^{10}$ A personal interview with the Director of School Mr.Rizgar Sadiq Abdulrahman, 7/2/2012.
}

\section{Gathering of informations and analysis approach}

The information of the research samples are obtained according to two researchs tools for gathering information.

\section{Architectural Plan Analysis.}

Determines of the planning, design, site of the gardens and their distribution in school according to the basic design.

\section{Individual interviews.}

In personal interviews with professionals and related people was to inquire and to monitor 
certain aspects of the research necessary to supplement the data obtained. The interview with some people is very important to express their opinion on the subject, such as director of school buildings in the Directorate of Education, and with school administrators and their collaborators.

\section{Observation}

The visiting to the school sites several times for each sample in an attempt to study the reality of the gardens of those schools, these observations may include the following aspects:

Composition of open spaces include(the most negative aspects of the garden, service operations, maintenance, natural components, the size of open spaces, their distribution in the school and its compliance with the standards).

\section{RESULTS AND DISCUSSION}

\section{Architectural Plans Analysis}

The data in table (1) indicated that the there wasn't much interest of school gardens, particularly in "Kawa" high school, which is the oldest high schools and many generations were graduated in Duhok and neighbors. This is due to its old design of green area of the school, about $13.5 \%$ and this is less comparing to the international standards to be allocated $50 \%$ of the total area of the space of green, as well as the local standards to be allocated $20 \%$ of green spaces (Sharbazhery:2002). While schools established after the nineties, the percentage of space green in the elected samples such as (Amad, Midia, Lavan, Sefin, Nsepin and Simerkh) $(37.5 \%, 28.2 \%$, $45.7 \%, 41 \%, 38.1 \%, 50 \%$ ), Table(1) according to local Standards $20 \%$ of green spaces, while the rest of the samples (Zirka, Zanisty and Awaz) were (4\%, 6.6\% and 12\%), Table(1) do not fall under the local standard. Only one school within this sample which is "Simerkh" high school of boys, has green area of 50\% of the site area which is within the international standards to be allocated $50 \%$ of the total area of green space as mentioned by (Sharbazhery:2002) Figure (2).

Through the interviews with specialists in this field they appointed that the area of the site school is determined by the land allocated of city planning (urban planning) and not the site plan, which is clarified by the Director of school Buildings in the Directorate of Education in Duhok that the implementation of the planned school project, which includes (classroom, laboratory ... etc.). The remaining space is allocated for gardens. They also pointed out that there is no standard for the allocation of green space for the project planning and construction of schools and this is how appeared during the surveying that the random green spaces in these samples as mentioned above, where they differ from school to school according to the area of the land. Also what mentioned by the specialists in the school buildings, the allocated area for garden is limited by supervisors on construction of school for it creating a problem for the school and for the Directorate of Education due to the lack of specialist's gardeners and do not paying to the management of these gardens*. As we know that the gardens need continuous management and service for student recreation, and create an atmosphere of fun from beautiful landscapes, or it'll turn out to barren sand land and place for gathering of student's garbage.

Table (1): Total area of buildings, concrete and green space of selected schools.

\begin{tabular}{|c|c|c|c|c|c|c|c|}
\hline \multirow[t]{2}{*}{ School } & \multirow{2}{*}{$\begin{array}{c}\text { Total Area } \\
\left(\mathrm{m}^{2}\right)\end{array}$} & \multicolumn{2}{|c|}{ Building Area } & \multicolumn{2}{|c|}{ Concrete Areas } & \multicolumn{2}{|c|}{ Green Space } \\
\hline & & $\left(m^{2}\right)$ & (\%) & $\left(m^{2}\right)$ & (\%) & $\left(m^{2}\right)$ & (\%) \\
\hline Amad & 4455 & 1833 & 41.10 & 948 & 21.40 & 1674 & 37.50 \\
\hline Midia & 6935 & 1823 & 26.30 & 3158 & 45.40 & 1954 & 28.20 \\
\hline Zirka & 6771 & 1915 & 28.30 & 4582 & 67.70 & 274 & 4 \\
\hline Lavan & 7822 & 1700 & 21.7 & 2550 & 32.6 & 3572 & 45.7 \\
\hline Zanisty & 7302 & 2121 & 29 & 4701 & 64.40 & 480 & 6.60 \\
\hline Sefin & 6054 & 1753 & 29 & 1825 & 30 & 2476 & 41 \\
\hline Nsebin & 6454 & 1332 & 20.60 & 2663 & 41.30 & 2459 & 38.10 \\
\hline Awaz & $3663 \mathrm{ul}$ & 1616 & 44 & 1612 & 44 & 435 & 12 \\
\hline Kawa & 9230 & 3165 & 34.30 & 4815 & 52.20 & 1250 & 13.50 \\
\hline Simerkh & 7298 & 1687 & 23 & 1966 & 27 & 3645 & 50 \\
\hline
\end{tabular}

Source: done by the researcher 


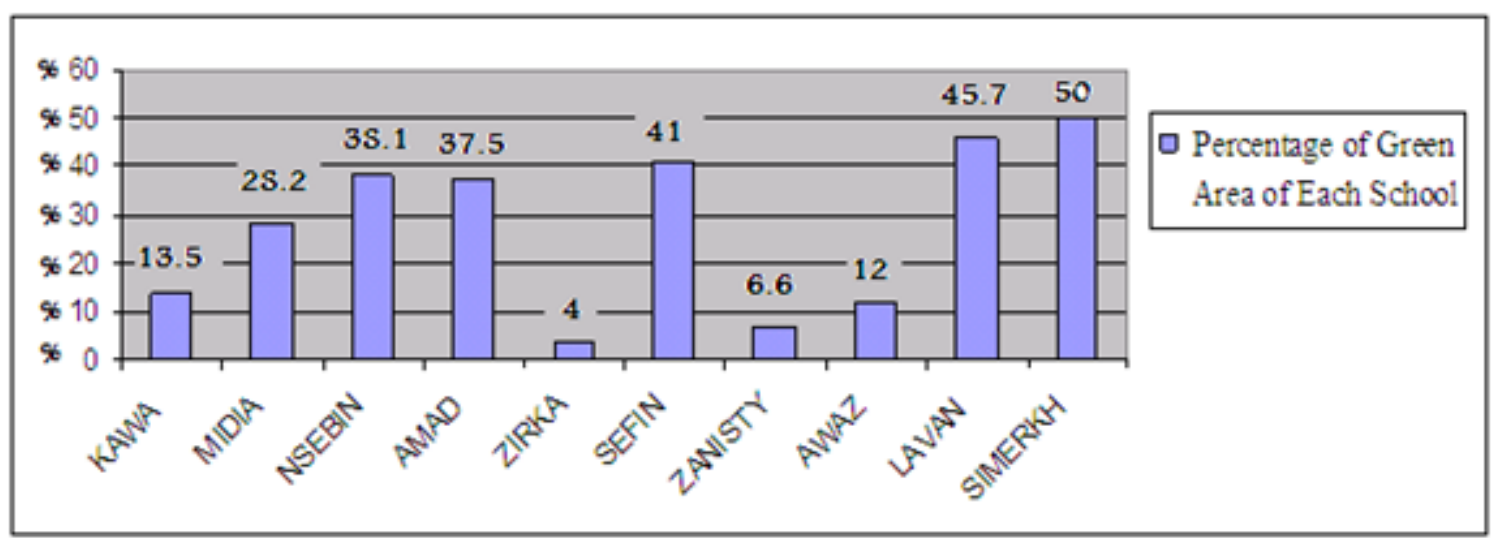

Fig. (2): Percentage of green area of each school (samples)

\section{Observations}

Some of the identified phenomena through the observation of the visiting to research the chosen schools found that the volume of open spaces in the samples of high schools (Amad, Midia, Lavan, Sefin, Nsepin and Simerkh) schools were identical to the local planning criteria. While internationally the size of one spaces of the sample research do not conform to standards except (Simerhk) high school, where the total percentage of the open spaces are $(50 \%)$. The most important observe thing in all sample of schools (Kawa, Midia, Nsebin, Sefin and Lavan) the used area as green areas are follows $(32.6 \%, 19.2 \%, 12.2 \%, 19.4 \%$, $11.6 \%)$ they defined area as a green space for the above samples as in Table (2).
The second half of the samples, which included schools (Amad, Zirka, Zansty, Awaz and Simerkh), the utilized garden $(55.6 \%, 100 \%$, $100 \%, 85 \%, 93.2 \%)$. within the actual space of the green for these schools Table (2).

As for service and maintenance, it has been observed through the answers of principals (Amad, Sefin, Nsebin, Lavan and Awaz) that there is no service and maintenance for garden and there is no appointment of an official to manage this important aspect of the school .While the rest of the samples (Kawa, Midia, Zirka, Zansty and Simerkh) had formal official, but not as a practitioner or holder of certificate of agricultural for the management of these gardens.

Table (2): Areas and percentage of used green area from total green areas.

\begin{tabular}{cccc}
\hline Name of School & Total Green Area & \multicolumn{2}{c}{ Used Green Area } \\
\cline { 3 - 4 } & & $\left(\mathbf{m}^{\mathbf{2}}\right)$ & $\mathbf{( \% )}$ \\
\hline Kawa & 1250 & 408 & 32.6 \\
\hline Midia & 1954 & 376 & 19.2 \\
\hline Nsebin & 2459 & 300 & 12.2 \\
\hline Amad & 1674 & 931 & 55.6 \\
\hline Zirka & 274 & 274 & 100 \\
\hline Sefin & 2476 & 480 & 19.4 \\
\hline Zanisty & 480 & 480 & 100 \\
\hline Awaz & 435 & 370 & 85 \\
\hline Lavan & 3572 & 415 & 11.6 \\
\hline Simerkh & 3645 & 3398 & 93.2 \\
\hline
\end{tabular}

Source: done by the researcher

* A personal interview with engineer (Yarewan Nisam) -Director of the school building in the general directorate of education $(2 / 1 / 2012)$ 
All samples even the Simerkh high school contained 460 plants as the highest number than other high school schools and then Zanisty 120, Lavan 83, Midia 80, Amad 58, Awaz 51, Kawa 37, Nsebin 26, and in Safin high school ranked last in terms of the number of plants in it which was only 9 , and the total numbers of plants in all high schools (samples) amounted to (976) Table (3).
It is clear from above that there is a difference in the size of the allocated area for the establishment of parks, as it was observed that $60 \%$ of the total samples and this is high (Amad, Midia, Lavan, Sefin, Nsebin and Simerkh) had spaces parks and within the local standards and that $40 \%$ of high schools (Zirka, Zansty, Awaz and Kawa) do not apply to local standards.

Table (3) Total of the plants in studied school gardens:

\begin{tabular}{|c|c|c|c|c|c|c|c|c|c|c|c|c|}
\hline \multirow[b]{2}{*}{ í } & \multirow[b]{2}{*}{$\frac{\frac{0}{7}}{\frac{\pi}{2}}$} & \multicolumn{10}{|c|}{ Number of Plants per school } & \multirow{2}{*}{ 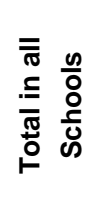 } \\
\hline & & 宽 & $\frac{\frac{\pi}{0}}{\frac{0}{\Sigma}}$ & 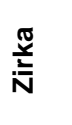 & స్ & $\frac{\overrightarrow{0}}{\frac{\pi}{5}}$ & 心 & 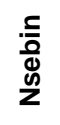 & 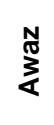 & 疍 & 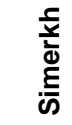 & \\
\hline 1 & Trees & 53 & 24 & 41 & 34 & 65 & 8 & 17 & 13 & 25 & 88 & 368 \\
\hline 2 & Shrubs & 3 & 48 & 4 & 49 & 52 & 1 & 9 & 11 & 12 & 169 & 358 \\
\hline 3 & $\begin{array}{c}\text { Flowering } \\
\text { bulbs }\end{array}$ & 0 & 4 & 0 & 0 & 0 & 0 & 0 & 20 & 0 & 188 & 212 \\
\hline 4 & $\begin{array}{c}\text { Herbaceous } \\
\text { plants }\end{array}$ & 2 & 4 & 7 & 0 & 3 & 0 & 0 & 6 & 0 & 14 & 36 \\
\hline 5 & $\begin{array}{c}\text { Succulent } \\
\text { and Cactus } \\
\text { plants }\end{array}$ & 0 & 0 & 0 & 0 & 0 & 0 & 0 & 1 & 0 & 1 & 2 \\
\hline $\begin{array}{r}\text { Tot } \\
\mathrm{e}\end{array}$ & $\begin{array}{l}\text { I of Plants in } \\
\text { ch School }\end{array}$ & 58 & 80 & 52 & 83 & 120 & 9 & 26 & 51 & 37 & 460 & 976 \\
\hline
\end{tabular}

Source: done by the researcher

It was also found that the actual unexploited of the allocated area for gardens due to the lack of attention to this aspect by the Ministry of Education and the General Directorate for Education, despite of the existence of a special unit as the Unit for school gardens in the Directorate of Education in Duhok. While for samples in which the real exploitation as a green space of the school Figure (3), is not in good condition and have many problems including lack of the element and diversity plant in agriculture, lack of availability of shadows, the lack of quiet places to take rest and sit down, do not selecting resistant and appropriate plants for the area and randomly plantation without following the basics of planning, design and follow scientific methods in agriculture, as well as the lack of service and maintenance and the absence of scientific supervision and agricultural specialist. 


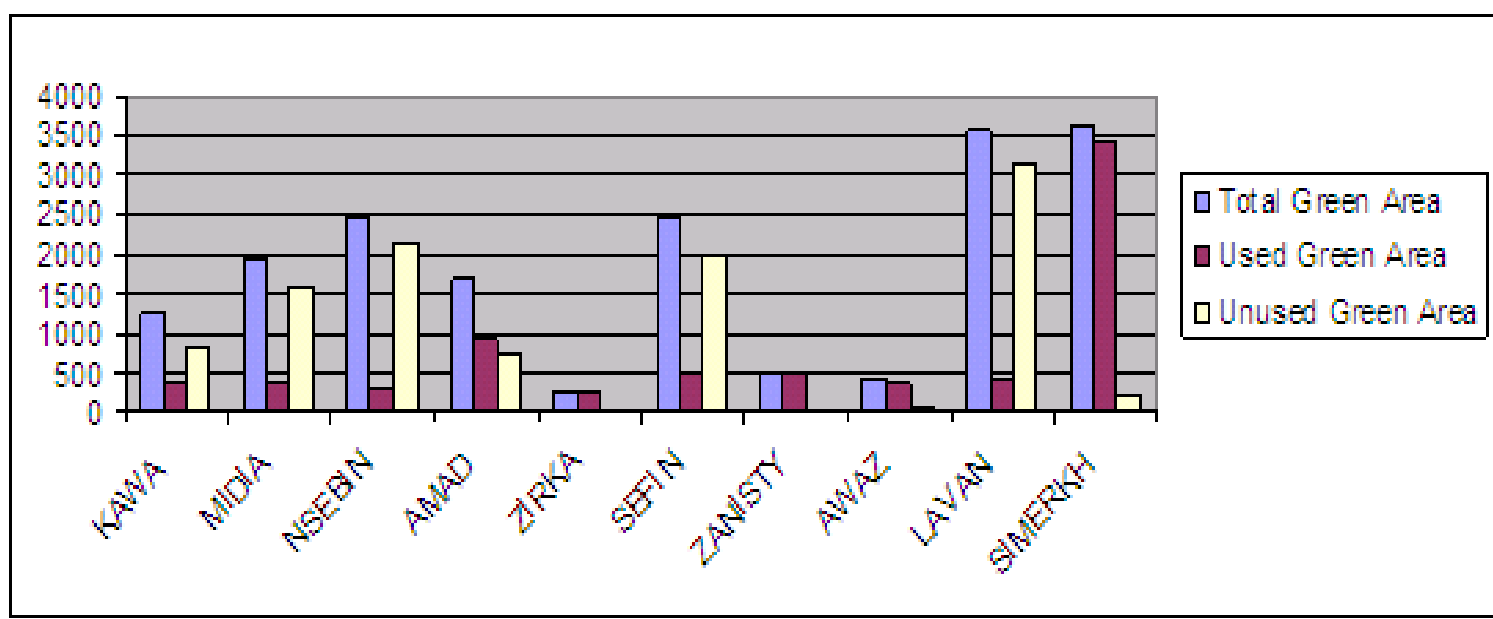

Fig. (3): Total, used and unused green areas

\section{REFERENCES}

1- Blair, D. (2009). The child in the garden: An evaluative review of the benefits of school gardening. Journal of Environmental Education. Vol. 40, No. 2.

2- Chawla, I. (1994). Gardening as an initiation in to environmental action. Amer. Hort. 73 (7): 6-7.

3- Fleszar, E. and Gwardys-Szczęsna, S. (2009). The school gardens in preserving biology diversity for education of sustainable development, Bulgarian Journal of Science and Education Policy (BJSEP). Vol.3, No. 2, University of Szczecin, Poland.

4- Harvey, M. (1989). The relationship between children's experiences with vegetation on school grounds and their environmental attitudes. J. Environ. Educ. 21 (2): 9 - 15.

5- Inko-Tariah, D. J. (2010). Improving the school environment with the school gatdens: Going back to the basics. Nigerian Journal of Agriculture. Food and Environment. 6 (3 and 4): 73-75.

6- Lohr, V. I. and Relf, P. D. (2000). An overview of the current state of human issues in horticulture in the United States, Hort. Technology, 10(1): 27-33.

7- Lownds, N. (2000). A child's Gardening. The American Gardner, March - April: 19 - 21.

8- Pranis, E. and Hale, J. (1999). Grow Lab.: A complete Guide to Gardening in the classroom. National Gardening Association - USA.

9- Rasol, T. N. (1988). Landscape Design. Baghdad, Iraq. (In Arabic).

10- Relf, P. D. (1992). Human Issues in Horticulture. Hort. Technology 2 (2): 159 - 171.

11- Skinner, E. A. and Chi, U. (2012). Intrinsic motivation and engagement as (Active Ingredients) in garden-based education: Examining models and measures derived from self-determination theory. The Journal of Environmental Education, Vol. 43, Issue 1. 2012, Educational Assessment Group, Pages 16 - 36 .

12- Sharbazhery, A. O. M. (2002). Design fundamental of school gardens between actuality and ambition. MSc. Thesis. College of Agriculture, University of Baghdad, Iraq.

13- Waliczek, T. M. and Zajicek, T. M. (1999). School gardening improving environmental attitudes of children through hands - on learning. J. Environ. Hort. 14 (4): $180-184$ 


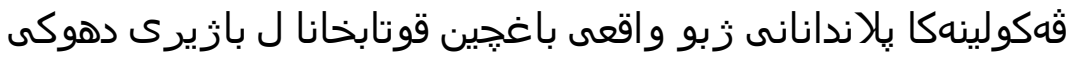

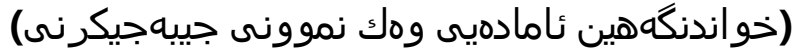

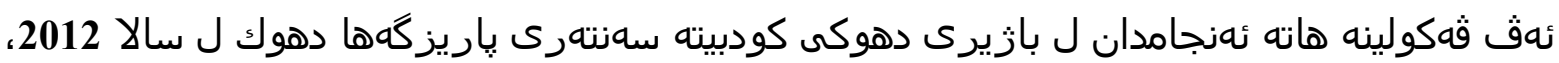

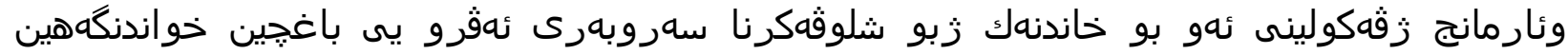

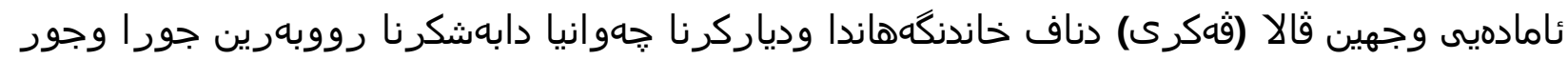

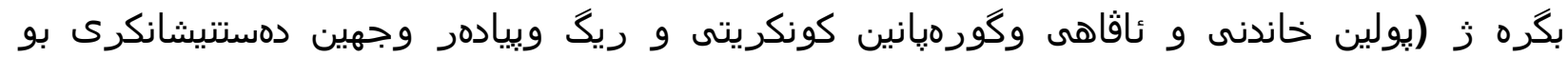

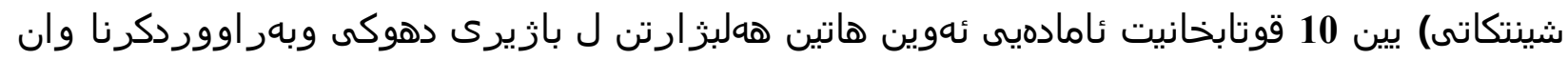

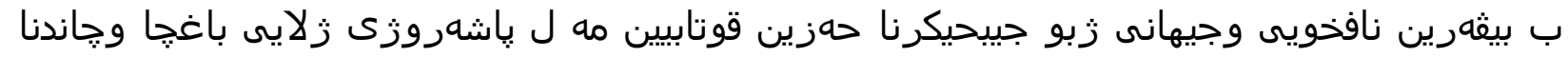

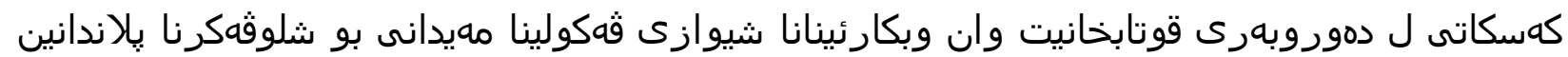

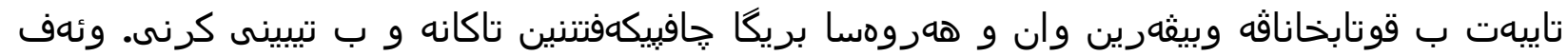

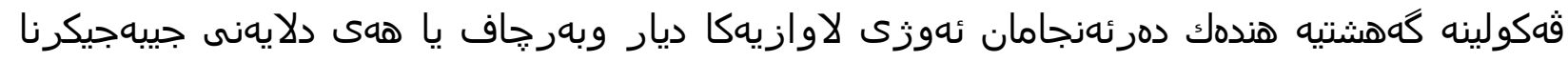

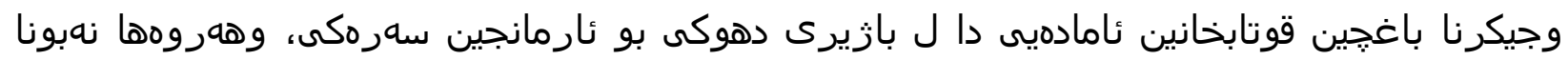

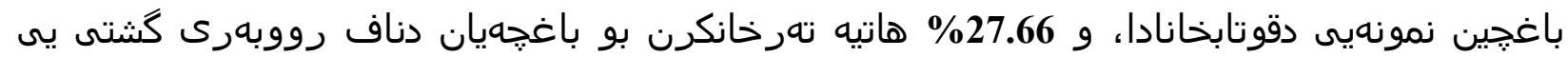

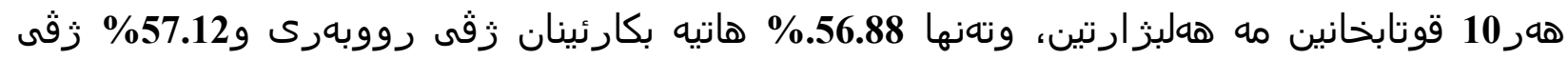

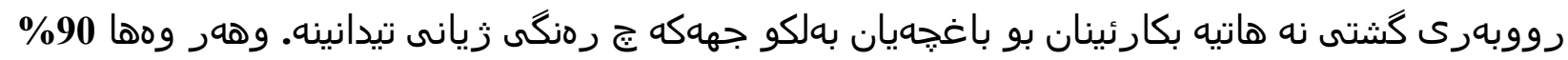

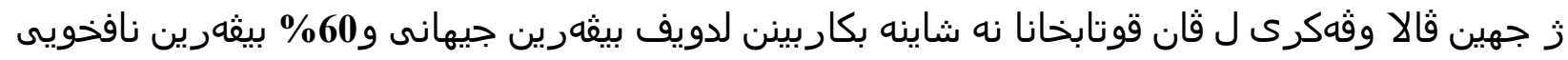

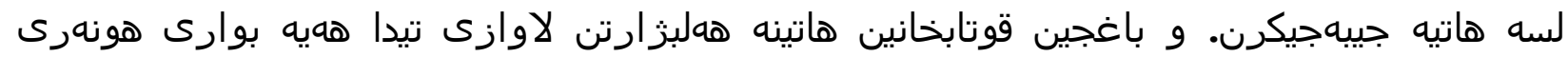
ئهدازياريا باغجا دا كو بشيونه

دراسة تخطيطية لواقع تصميم الحدائق المدرسية في مدينة دهوك

(المدارس الاعدادية كنموذج تطبيقي)

الخلاصة

الفذت هذه الدر اسة في مدينة دهوك مركز محافظة دهوك في 2012 واستهدف الدراسة تحليل واقع حال

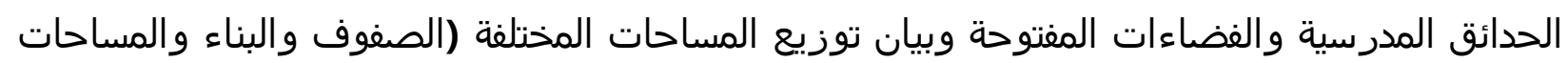
الكونكريتية والممرات والمساحات المخصصة للفضاء الاخضر) لعشرة مدارس اعداءلة اعدادية منتخبة في

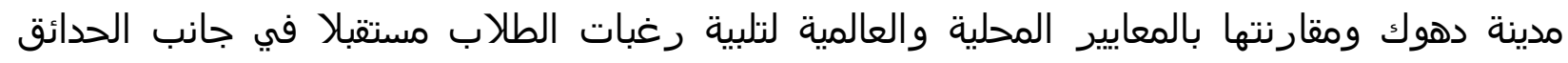
والفضاءات الخضراء حول مدارسهم باستخدام اسلوب الدراسة الدها الميدانية لتحليل المخططات المعات المعمارية الخاصة للمدارس المنتخبة وقياسها ومن خلال الملاحظة والمات المقابلات الشخصية. توصلت الدارية الدراسة الى الى عدة نتائج او استنتاجات تلخصت فيمايلي وجدود قصور واضح في درجة المدارئة تحقيق الحدائق المدرسية في

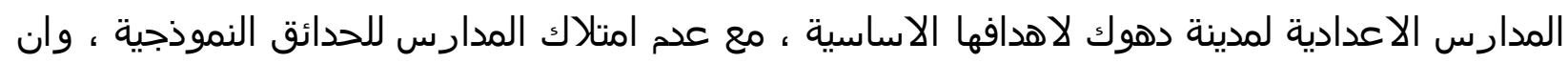

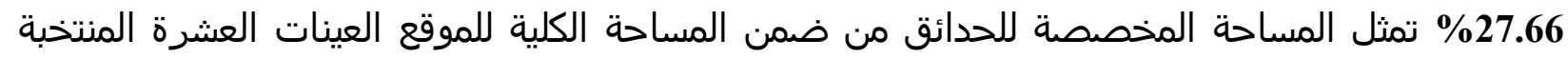

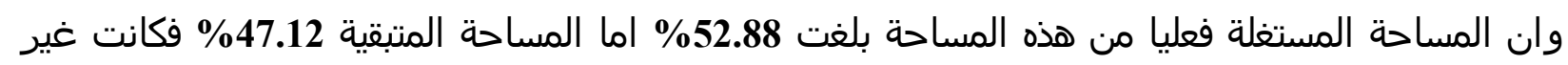

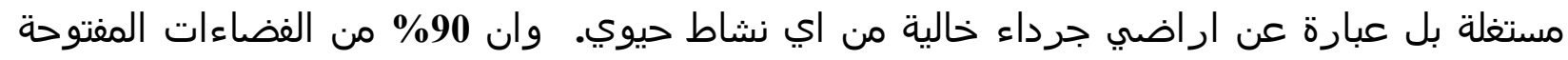

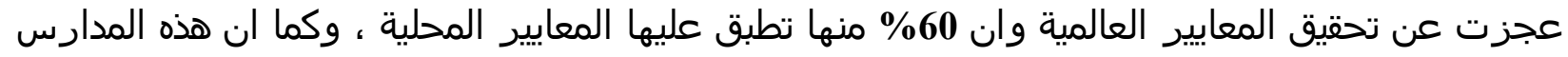

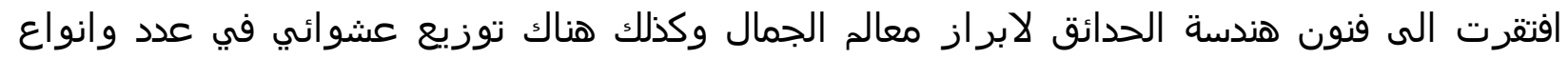
النباتات في تلك الحدائق. 